\title{
Knowledge and Attitudes Towards Learning English Among Saudi Students in Globe Institute in Exeter (UK)
}

\author{
Sami Mohammed Amri Almalki \\ Taif University, Taif, Saudi Arabia \\ Exeter University, Exeter, United Kingdom
}

\begin{abstract}
Considering the vital role that the English language plays in contemporary society and the changing needs of institutions around the world, gaining a thorough knowledge of English can help people in a number of ways. The primary aim of this research is therefore to identify the levels of knowledge of English and attitudes towards learning English among Saudi students at the Globe English institute, Exeter, UK. To achieve this aim, a structured questionnaire is designed in order to gather related data from a sample of 30 respondents, comprising 17 male and 13 female students. This study seeks to establish the relationship between knowledge of English, attitude towards learning English, and demographic factors such as the age, gender, and major of respondents. According to the survey findings, it may be stated that there is a significant favourable relationship between knowledge of English and attitude of respondents towards learning the English language. The identified statistical results will be discussed as they pertain to the preceding literature.
\end{abstract}

Keywords: knowledge, attitude, vocabulary, EFL

\section{Introduction}

According to Sultan (2003), English is taught in Saudi Arabia as compulsory subject that is meant to be taught from intermediate school up until university where it is supposed to be taught throughout the first year as part of the preparatory year programme (PYP). These days English revolves around every aspect of life and this fact is fully realised. It is especially important for those who want to pursue their higher education abroad where the only medium of instruction is English. In the light of this, I would like to carry out a study among Saudi students coming to the UK to pursue Higher Education with a special focus on those studying at Exeter's Globe school. There are a number of aspects to my study.

\section{The Aim of the Study}

The study aims to measure the student's competence in vocabulary while studying back in Saudi Arabia. In addition, it seeks to explore their beliefs about having to learn English as a foreign language, to find out the students' knowledge and attitudes towards learning English in relation to the following: gender, age, and speciality.

Sami Mohammed Amri Almalki, lecturer, English Language Centre, Taif University; Ph.D. student, Faculty of Education, Exeter University. 


\section{The Saudi Context}

The Saudi Arabian government has undertaken a policy shift towards teaching the English language, as it has come to recognise the value of English as a means of allowing Saudi citizens to participate in the global market in areas such as education, trade, employment, and cultural exchange (Karmani, 2005). In 2006, the government initiated school reforms intended to improve literacy in Arabic (KSA Ministry of Education, 2006), and in 2010 it was agreed that English instruction should be compulsory (KSA Ministry of Education, 2010). A direct result of this policy, it is now a requirement to teach English starting at primary school level and ultimately to prepare a large number of students to undertake their higher education in English.

\section{Literature Review}

Understanding students' attitudes and beliefs is crucial in Second Language Acquisition (SLA) because of the enormous variety that exists within the student population, and the fact that differences at the individual level may affect learning outcomes, either in positive or negative ways (Skehan, 1989; Dörnyei, 2005). Learning a language is affected by the attitudes the learners have towards the language. When students exhibit positive attitudes towards the language, the learning process becomes easier. Moreover, studies revealed that attitude affect achievement (Fakeye, 2010). Thus, the literature reveals that attitudes and motivation play a vital role in the acquisition of second language and language in general. The emotions that a student experiences in the classroom can have a significant influence on the effectiveness and degree of learning that takes place. For this reason, there is a large body of literature concerning attitudes, beliefs, and "affect" within SLA classrooms (Scovel, 1978, pp. 129-142; Arnold, 1999). Similarly, different forms of intrinsic and extrinsic motivation can influence academic success (Dörnyei, 1998), and it is very useful for teachers to be aware this so that they can encourage each student in the best possible way. Some research has shown that a number of Saudi students experience a certain amount of anxiety when learning English. This seems to affect female students more than males (Al-Saraj, 2014).

\section{Operationalization of the Constructs}

(1) Attitudes toward learning English: The answers given by the students express their feelings about learning the English through a Likert scale;

(2) Knowledge towards learning English: The scope of which the student's ability to memorise vocabulary through the study of English in Saudi Arabia from Elementary school to high school and (PY) year at University.

\section{Background Data}

(1) Gender: Students chose female or male depending on their gender;

(2) Students' ages: between 20-25, 26-30, 31-35, and 36-40;

(3) Their major: Students either chose majors in English, Physics, Social Sciences, or other.

\section{Hypotheses}

My research aims to explore knowledge and attitudes towards learning English in the Globe institute in Exeter (UK). The Saudi students also test the following hypothesis: 


\section{Hypothesis 1}

$\mathrm{H}_{1}$ : There is a statistically significant correlation between students' knowledge of learning English and their attitude towards it.

$\mathrm{H}_{01}$ : There is no statistically significant correlation between students' knowledge of learning English and their attitude towards it.

\section{Hypothesis 2}

$\mathrm{H}_{2}$ : There is a statistically significant influence of student's gender on their knowledge of learning English.

$\mathrm{H}_{02}$ : There is no statistically significant influence of student's gender on their knowledge of learning English.

\section{Hypothesis 3}

$\mathrm{H}_{3}$ : There is a statistically significant influence of students' speciality on their attitude towards learning English.

$\mathrm{H}_{03}$ : There is no statistically significant influence of students' speciality on their attitude towards learning English.

\section{Hypothesis 4}

$\mathrm{H}_{4}$ : There is a statistically significant influence of age on students' knowledge and learning of English language.

$\mathrm{H}_{04}$ : There is no statistically significant influence of age on students' knowledge of English.

\section{Hypothesis 5}

$\mathrm{H}_{5}$ : There is a statistically significant of students' attitude predicted by their knowledge, gender, and age.

$\mathrm{H}_{05}$ : There is no statistically significant of students' attitude predicted by their knowledge, gender, and age.

Table 1

Independent and Dependent Variables

\begin{tabular}{lll}
\hline Hypothesis & Independent variable & Dependent variable \\
\hline Hypothesis 1 & $*$ Not Applicable & $*$ Not Applicable \\
Hypothesis 2 & Gender & Knowledge of learning English \\
Hypothesis 3 & The major & Attitude towards learning English \\
Hypothesis 4 & Age & Knowledge of learning English \\
Hypothesis 5 & Knowledge, gender, and age & Attitude \\
\hline
\end{tabular}

Note. ${ }^{*}$ In terms of correlation, there are no dependent or independent variables when talking about correlation, just consider variables.

\section{Methodology}

This study maintains the same basis as prior research studies and designed hypotheses, and primarily intends to gauge the attitudes of Saudi students towards learning English and their respective knowledge of the language. In this section provides the design of the research method, the sampling procedures and research instruments used, the related validity and reliability of these research instruments, and finally the ethical issues and research limitations that were noted whilst gathering data for this study. 


\section{Research Design}

The data generated by this study was quantitative, and was gathered using a structured questionnaire. The responses received from study participants were subjected to statistical evaluation in order to test the constructed hypotheses; in other words, in order to decide whether to accept or reject the hypotheses. The selection of questionnaires as the research instrument for this study was based on the research questions regarding the demographic characteristics of participants, participants' attitudes towards learning English (20 items) and participants' knowledge of English (20 items). Refer to Appendix A.

\section{Sampling and Participants}

This research study employs the technique of "Convenient Sampling". This makes it easy for the researcher to approach people to gather data, since each individual within the population does not have an equal opportunity of being selected for participation in the study (Babbie, 2001). In terms of sample size, the sample used for this research comprised a total of 30 Saudi students from academic year 2014/2015 at the Globe institute. Of these 30 students, 17 were male (56.7\%) and 13 were female (43.3\%). The demographic breakdown was as follows: Around 16 students were between the ages of 26 and 30 (53.3\%); around 11 were between 31 and 35 (36.7\%) and three were between 36 and 40 (10\%). With regard to study majors (in Saudi Arabia or continuing here in Exeter University after achieving the required score in IELTS ), four students were studying English as a major (13.3\%), four were majoring in physics (13.3\%), 15 were majoring in social sciences $(50 \%)$, and seven were majoring in other areas of study $(23.3 \%)$. In order to confirm the robustness of this research, it was ensured that the grades of participating students would not have any effect on their survey responses, as they had all studied English in Saudi Arabia at primary, intermediate, and secondary levels. However, this study is only aimed at determining the attitudes of participating students towards learning English and their knowledge of the English language.

\section{Materials}

The study employed a variety of research materials, including questionnaires (used as a research instrument), respondent consent forms (see Appendix B, and statistical tools such as SPSS, which were used to analyse the collected data (see Appendix C). The section below will describe the primary research instrument (i.e., the structured questionnaire) in greater detail.

\section{The Instrument}

The structured questionnaire includes at least 20 items intended to reveal respondents' attitudes towards learning English, while a further 20 items are intended to reveal the level of participants' English vocabulary. The questionnaire items relating to knowledge were gathered from English textbooks used to teach English at primary, intermediate and PYP level in Saudi Arabia. The researcher has therefore assumed that all participants have received adequate knowledge of English in their previous schooling and PYP. The concept and guidelines underlying this section of the questionnaire were based on the concepts described by Burton et al. (1991). The questionnaire items were written by me except items number 10, 17, and 20 which were taken from $E F L$ Students' Attitudes Towards Learning English Language: The Case of Libyan Secondary School Students (Mohammed, Majied, \& Hana, 2012), while the items relating to attitude were based on the guidelines set out by Oppenheim (2000). A five-point Likert scale is used in the questionnaire, as this provides a concrete basis 
for analysing the attitudes and opinions of respondents. According to Cherly Qing (2010), the Likert scale is generally helpful in revealing respondents' viewpoints and also generates accurate data for the purposes of measurement. While the items relating to attitude were based on a 5-point Likert scale, the items concerning knowledge took the form of multiple choice questions with four possible answers, which were later coded as "correct" or "incorrect". The questionnaire employs closed-ended questions, which generate responses that are suitable to be employed as "statistical results" and to be subjected to "statistical treatment". Responses to closed questions also allow various comparisons across different groups within the targeted sample (Oppenheim, 1992, p.115).

\section{Validity of Instrument}

According to Oppenheim (1992, p. 144), the term "validity" refers to the evaluation of the soundness and effectiveness of any item, score, or question. This is sometimes referred to as "content validity". In order to ensure the validity of the questionnaire as a research instrument, the questionnaire was modified after seeking expert opinions from professionals at Newcastle University in Australia. Two experts were elected from the education department and two from the English department, including an expert from Taif University in Saudi Arabia. After receiving feedback from these individuals, the questionnaire was found to be generally satisfactory in reflecting the major objective of the study, although certain amendments were suggested: These amendments included several modifications to wording/sentence structure and the reduction of similarities between a number of items (for example, items $6,13,17$, and 20 in the attitude section). The items in the knowledge section were deemed to be adequate, as they were all taken from English textbooks and none of the experts made any comments on these items. Once all the required modifications had been carried out, the whole questionnaire was again reviewed by all the experts and was judged to be ideal for achieving the primary objective of the study (see Appendix A).

\section{Reliability of Instrument}

In accordance with Oppenheim's theory (1992, p. 144), reliability relates to the transparency, consistency and repetition of constructs, as well as to the likelihood of gaining a significant number of similar results if the constructs were to be replicated. Reliability testing indicated that there were no relevant errors within the questionnaire. Cronbach's alpha was used to test the reliability of this study. This test verifies the "internal consistency" of items, with the value of the "alpha" varying between 0 and 1, which relates to the stability of the achieved outcomes. In order to fully ensure the reliability of research, some statisticians recommended that the value of Cronbach's alpha exceed 0.7 (e.g., Spiliotopoulou, 2009; Pallant, 2013). When the reliability of this study was tested using the SPSS statistical tool, the research instrument was ultimately proven to be a reliable instrument for gauging the attitudes towards learning English and knowledge of English among Saudi students at the Globe institute in Exeter, UK. The reliability of both items (i.e., knowledge and attitude) was tested. Once all the data was encoded in SPSS, certain items were once again coded (for example items 4, 6, 7, 8, 11, 14,17 , and 20). All negative questions were thus modified in such a way as to reflect positive connotations: For instance, the item "English classes are not interesting" was encoded as "strongly agree" (5). The item was reworded as "English classes are interesting", and the scale was reversed, i.e., "strongly disagree" (1). The reliability of the questionnaire was showed a reasonable and acceptable internal consistency among the attitude items, generating an alpha value of $0.752(75.2 \%)$. No omissions of the items were therefore deemed to be necessary (see Table 2). For the knowledge reliability was showed a reasonable and acceptable internal 
consistency among the knowledge items, generating an alpha value of 0.749 (74.9\%). No omissions of the items were deleted therefore deemed to be necessary (see Table 3).

Table 2

Reliability Statistics of Attitudes Items

\begin{tabular}{ll}
\hline Cronbach's alpha & N of items \\
\hline .752 & 20 \\
\hline
\end{tabular}

Table 3

Reliability Statistics of Knowledge Items

\begin{tabular}{ll}
\hline Cronbach's alpha & N of items \\
\hline .749 & 20 \\
\hline
\end{tabular}

\section{Procedures}

The research process for this study consisted of carrying out a literature review and of designing questionnaire as a research instrument with the stated aim of measuring Saudi students' knowledge of English and attitude towards learning English at the Globe institute. The researcher refined and validated the questionnaire by seeking expert opinions. The "convenient sampling" technique was employed, with participants (i.e., Saudi students at the Globe institute) being approached and selected individually by the researcher at a monthly student community gathering. The researcher explained the overall concept of the study, and participants were asked to sign consent forms in line with the questionnaire's requirements. The questionnaires were completed by a targeted sample consisting of 30 participants, of which 17 were male and 13 were female. The collected responses were then encoded in SPSS, and various statistical techniques were employed in order to generate analytical results. These are described in further detail in the "Results" section below.

\section{Ethical Issues}

Certain ethical issues were prudently taken into consideration throughout the course of the study. Firstly, the study had to comply with the ethical standards of Exeter University. This was ensured by obtaining official approval from the university's management (see Appendix B). Secondly, participants completed the questionnaire voluntarily and were not compelled in any way. Participants' profiles and questionnaire responses were kept strictly confidential and were not seen by any third party to achieve the desired outcomes of the study, and all participants were explicitly given the choice as to whether they were willing to take part in the study. As well, all respondents were offered the option of receiving a copy of the final research study following its completion. Further to this, in adherence with Bell's (2005) suggestions, all questionnaire responses were shattered once the desired statistical results were obtained.

\section{Limitations of Study}

This study also exhibited certain research limitations: For instance, the limited timeframe allowed for the completion of the questionnaire and the relatively small sample size, which ultimately offered unrepresentative and non-generalised results. Also, because of the short time of this study the pilot was omitted in this small project. More detailed research would therefore be required to further elucidate the findings of this study. 


\section{Results}

Prior to carrying out analysis in SPSS, it is crucial to demonstrate that the data has been encoded in such a manner as to ensure that the attitude scale is observed as "averaged", since all items in this section of the questionnaire were added and divided by 20 , whereas for the calculation of the knowledge constructs, incorrect items were allotted a code of " 0 " and correct items were given a code of " 1 " (i.e., $0=$ incorrect, $1=$ correct). The following sections will evaluate the data and test the research hypotheses using statistical tools.

\section{Normality and Data Type}

Prior to evaluating the gathered data, again, it is crucial to assess the normal distribution of the results, which should demonstrate whether the data maybe considered to "parametric". Normality is a required precondition for statistical procedures such as ANOVA.

\section{Normality}

According to an accepted rule of thumb, normal distribution of results is necessary in order to determine whether gathered data may be considered to be "parametric" or "non-parametric". In this regard, therefore, the key dependent variables (i.e., knowledge and attitude) must be confirmed as being normally distributed in order for the data to be considered parametric. Statisticians have developed a range of statistical tests for this purpose; however, "eyeballing" has been determined to be the least complicated method of verifying normal distribution. This primarily involves generating a graphical representation of the data, i.e., by using a bell-shaped histogram to check whether the frequency of the results adheres to a bell-shaped curve. In addition to this, two other advanced statistical methodologies are highly recommended, namely the Kolmogrov-Smirnoc test and the Shapiro-Wilk test, both of which are considered to be suitable for small sample sizes ( $<60$ respondents). Both of these tests were carried out, and the results showed that the collected data related to a normally distributed population, with the alpha value $(p<0.05)$ indicating a normal distribution. The tests were run in SPSS and gave results of $\mathrm{KS}(30)=0.13, p>0.05$; SW $(30)=0.96, p>0.05$ for the attitude constructs, while results for the knowledge constructs were $\mathrm{KS}(30)=0.097, p>0.05$; $\mathrm{SW}(30)=0.955, p>0.05$, which may be considered as non-significant. Figures 1 and 2 show the results of these tests, both indicating normal distribution. It is therefore evident from the results of the Kolmogrov-Smirnoc test and the Shapiro-Wilk test for both dependent variables that the data can be considered to be normally distributed (see Table 4).

Table 4

The Normality Scores of Data Based on the KS and SW Tests

\begin{tabular}{lllllll}
\hline & \multicolumn{3}{c}{ Kolmogorov-Smirnov $^{\mathrm{a}}$} & \multicolumn{3}{c}{ Shapiro-Wilk } \\
\cline { 2 - 7 } & Statistic & Df & Sig. & Statistic & df & Sig. \\
\hline Knowledge & .097 & 30 & $.200^{*}$ & .955 & 30 & .227 \\
Attitude & .130 & 30 & $.200^{*}$ & .962 & 30 & .353 \\
\hline
\end{tabular}

Note. ${ }^{\text {a }}$. Lilliefors significance correction; *. This is a lower bound of the true significance. 


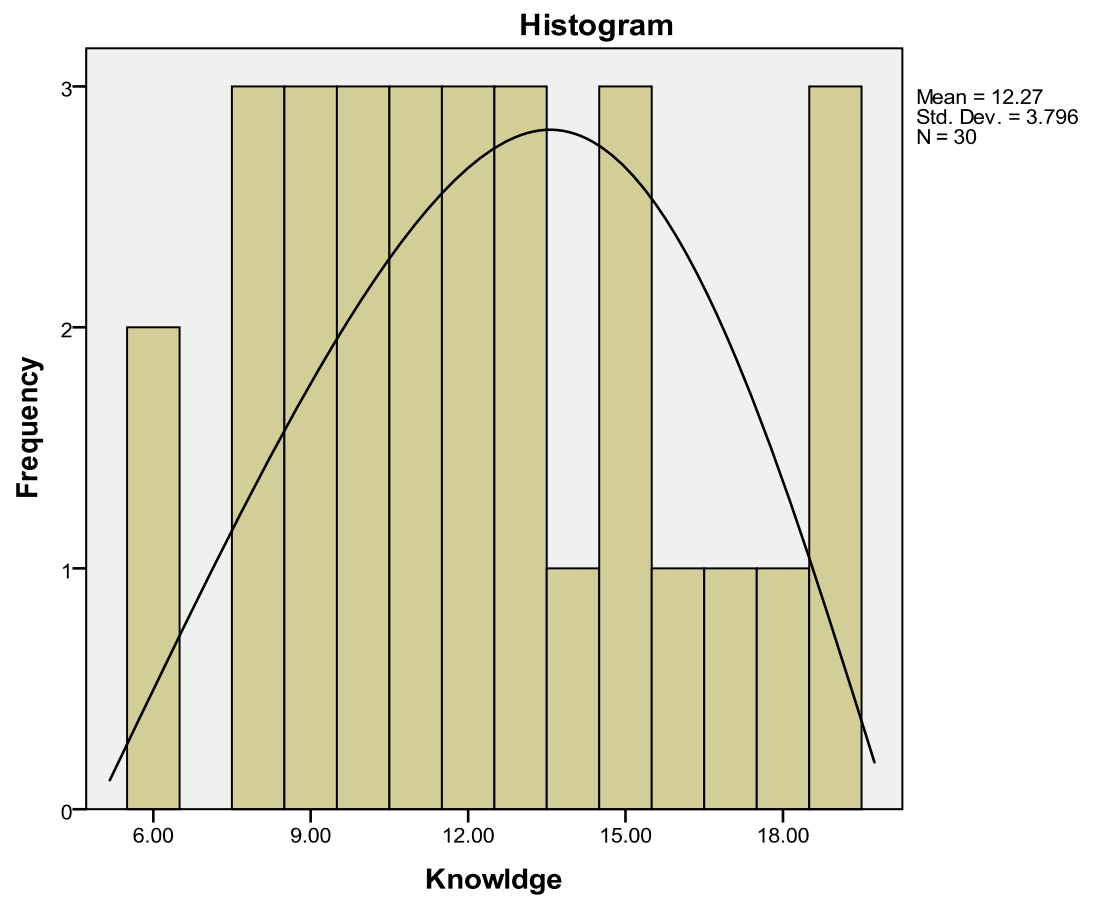

Figure 1. Histogram showing the distribution of students' Knowledge mean scores.

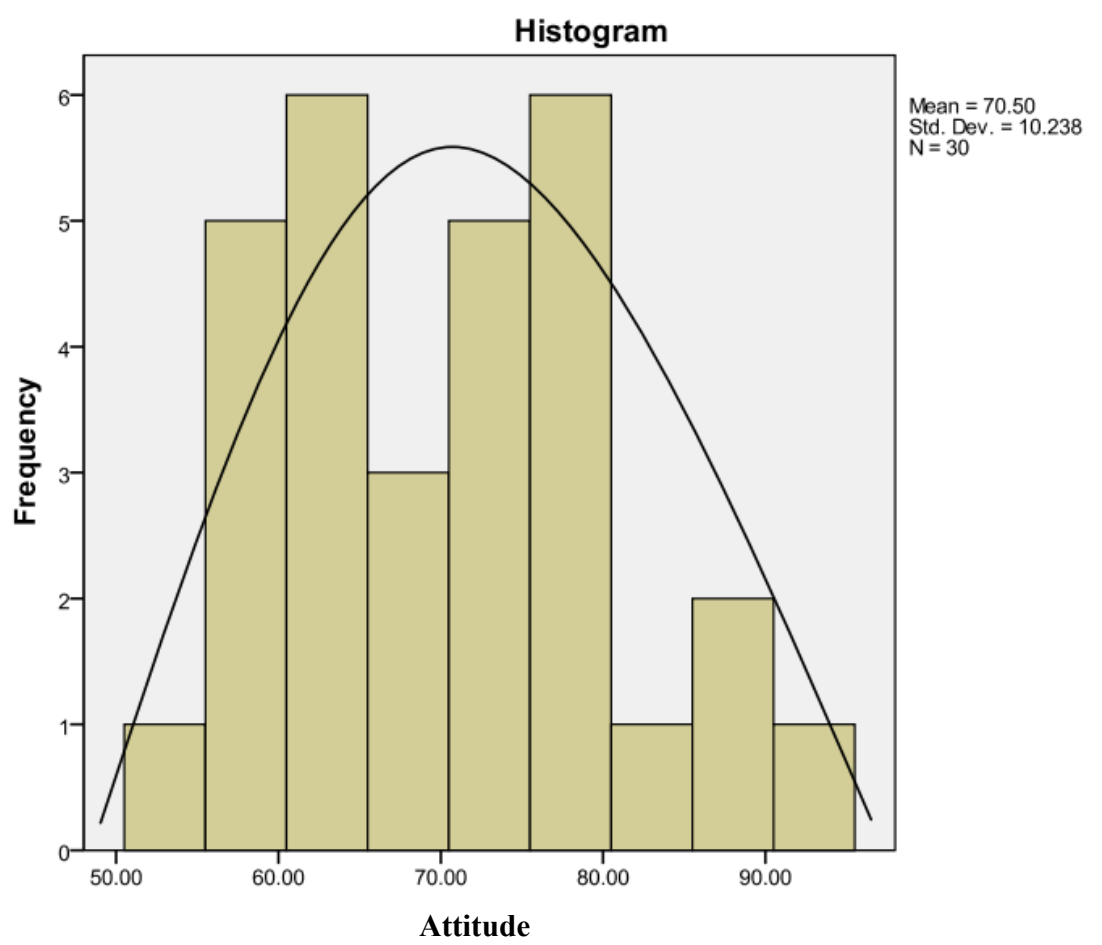

Figure 2. Histogram showing the distribution of students' Attitude means scores.

\section{Types of Data}

In order to achieve sound statistical results, in addition to meeting the criteria for normality, it is essential to ensure that gathered data also meets two additional criteria. Firstly, the data type must involve "intervals", 
and secondly, it must be ensured that each respondent has completed the questionnaire independently, without seeking help from others (such as through observation). Generally, a five-point Likert scale is treated as an "interval scale" in SPSS. Based on these criteria, it may be concluded that the data employed in this research study reflects parametric results, as parametric tests have been carried out to verify the constructed research hypotheses.

\section{Hypothesis Testing}

$\mathrm{H}_{1}$ : There is a significant correlation between students' knowledge of the English language and their attitude towards learning it.

To determine whether there is a significant correlation between participants' knowledge of the English language and their attitude towards learning it, a Pearson's $r$ correlation coefficient test was carried out. The Pearson's correlation test generates results ranging between 0 and 1 or 0 and -1 , where 1 or $-1(100 \%)$ reflects perfect correlation. The coefficient's value determines the level of the relationship and whether it is positive or negative, while the alpha level (sig.) indicates whether the correlation coefficient is significant. After running this test in SPSS, the results showed that there is a significant positive correlation between participants' knowledge of the English language and their attitude towards learning it: $\mathrm{r}(30)=0.594, p=0.01<0.05$ (see Table 5).

Table 5

Correlation Coefficient and Its Significance Between Attitude and Knowledge

\begin{tabular}{llll}
\hline & & Knowledge & Attitude \\
\hline \multirow{3}{*}{ Knowledge } & Pearson Correlation & 1 & $.594^{* *}$ \\
& Sig. (2-tailed) & & .001 \\
& $\mathrm{~N}$ & 30 & 30 \\
\hline \multirow{3}{*}{ Attitude } & Pearson Correlation & $.594^{* *}$ & 1 \\
& Sig. (2-tailed) & .001 & 30 \\
\hline
\end{tabular}

Note. ${ }^{* *}$. Correlation is significant at the 0.01 level (2-tailed).

$\mathrm{H}_{2}$ : Students' gender has a significant influence on their knowledge of English.

A t-test (also known as an Independent Samples T-test) was employed to test this hypothesis. The t-test usually compares mean scores from two independent groups (e.g., male and female) to determine whether they are significantly different. Using the t-test, it was discovered that equal variances are assumed between groups $(\mathrm{F}=3.289, p>0.05)$ and that gender does not have a significant effect on participants' knowledge of the English language $\mathrm{T}(28)=-1.227, p>0.05$. It may therefore be stated that males $(\mathrm{M}=11.529, \mathrm{SD}=3.046)$ perform similarly to females when learning English $(\mathrm{M}=13.23, \mathrm{SD}=4.53)$.

Table 6

Participants' Descriptive Statistics of Knowledge for Male and Female Students

\begin{tabular}{llllll}
\hline & Gender & N & Mean & Std. deviation & Std. error mean \\
\hline \multirow{2}{*}{ Knowledge } & Male & 17 & 11.5294 & 3.06426 & .74319 \\
& Female & 13 & 13.2308 & 4.53052 & 1.25654 \\
\hline
\end{tabular}


Table 7

Independent Samples T-test Table Showing Homogeneity of Variances and Difference Between Groups

\begin{tabular}{|c|c|c|c|c|c|c|c|c|c|c|}
\hline & & \multicolumn{3}{|c|}{$\begin{array}{c}\text { Levene's test for } \\
\text { equality of } \\
\text { Variances }\end{array}$} & \multicolumn{6}{|c|}{ T-test for equality of means } \\
\hline & & \multirow[t]{2}{*}{$\mathrm{F}$} & \multirow[t]{2}{*}{ Sig. } & \multirow[t]{2}{*}{$\mathrm{t}$} & \multirow[t]{2}{*}{ df } & \multirow[t]{2}{*}{$\begin{array}{l}\text { Sig. } \\
\text { (2-tailed) }\end{array}$} & \multirow[t]{2}{*}{$\begin{array}{l}\text { Mean } \\
\text { Difference }\end{array}$} & \multirow[t]{2}{*}{$\begin{array}{l}\text { Std. Error } \\
\text { Difference }\end{array}$} & \multicolumn{2}{|c|}{$\begin{array}{l}95 \% \text { Confidence } \\
\text { Interval of the } \\
\text { Difference }\end{array}$} \\
\hline & & & & & & & & & Lower & Upper \\
\hline \multirow{2}{*}{ Knowledge } & $\begin{array}{l}\text { Equal } \\
\text { variances } \\
\text { assumed }\end{array}$ & 3.289 & .080 & -1.227 & 28 & .230 & -1.70136 & 1.38653 & -4.54154 & 1.13883 \\
\hline & $\begin{array}{l}\text { Equal } \\
\text { variances not } \\
\text { assumed }\end{array}$ & & & -1.165 & 20.026 & .258 & -1.70136 & 1.45987 & -4.74634 & 1.34363 \\
\hline
\end{tabular}

$\mathrm{H}_{3}$ : Students' majors have a significant influence on their attitudes towards learning the English language.

Within the sample population, students' majors fall into four categories: English, physics, social sciences, and other subjects. To test this hypothesis, an Independent Samples One Way Analysis of Variance (ANOVA) test was carried out. ANOVA testing compares the means of three or more independent groups. The results of the Levene's test showed that the study data is homogeneous: $\mathrm{F}(3,26)=1.483, p>0.05$. Therefore, the ANOVA result is significant and can be used. We can see that the significance level is $0.001(p=0.001)$, which is below 0.05 and therefore indicates that there is a statistically significant difference among the major groups regarding attitudes towards learning English: $\mathrm{F}(3,26)=6.952, p<0.01$. We can see from Table 8 that there is a significant difference in this regard between students majoring in English and students majoring in Physics, Social Sciences, and other subjects.

Table 8

Tukey HSD Post-Hoc Test for Multiple Comparisons (Dependent Variable: Attitude, Tukey HSD)

\begin{tabular}{lllllll}
\hline \multirow{2}{*}{ (I) major } & \multirow{2}{*}{ English major } & Mean difference (I-J) & \multirow{2}{*}{ Std. error } & \multirow{2}{*}{ Sig. } & \multicolumn{2}{c}{$95 \%$ confidence interval } \\
\cline { 5 - 7 } & & & & & Lower bound & Upper bound \\
& Physics & $22.25000^{*}$ & 5.69504 & .003 & 6.6267 & 37.8733 \\
& Social & $18.18333^{*}$ & 4.53224 & .002 & 5.7499 & 30.6167 \\
\multirow{3}{*}{ Physics } & Another & $20.10714^{*}$ & 5.04811 & .003 & 6.2586 & 33.9557 \\
& English & $-22.25000^{*}$ & 5.69504 & .003 & -37.8733 & -6.6267 \\
& Social & -4.06667 & 4.53224 & .806 & -16.5001 & 8.3667 \\
\multirow{3}{*}{ social } & Another & -2.14286 & 5.04811 & .974 & -15.9914 & 11.7057 \\
& English & $-18.18333^{*}$ & 4.53224 & .002 & -30.6167 & -5.7499 \\
& Physics & 4.06667 & 4.53224 & .806 & -8.3667 & 16.5001 \\
\multirow{3}{*}{ another } & Another & 1.92381 & 3.68662 & .953 & -8.1898 & 12.0374 \\
& English & $-20.10714^{*}$ & 5.04811 & .003 & -33.9557 & -6.2586 \\
& Physics & 2.14286 & 5.04811 & .974 & -11.7057 & 15.9914 \\
\hline
\end{tabular}

Note. *. The mean difference is significant at the 0.05 level.

$\mathrm{H}_{4}$ : Age has a significant influence on students' knowledge and learning of the English language.

It was assumed that respondents' age has a significant effect on their knowledge of English. Using the Levene's test, it was found that the data meets the homogeneity of variances assumption, $\mathrm{F}(2,27)=1.714, p>$ 
0.05. Therefore, it was proved by ANOVA that there is no significant of participants age on their knowledge and learning of the English language, F $(2,27)=1.527, p=0.235>0.05$, moreover; the Tukey Post-Hoc test did not show any significant difference between any specific two groups $(p>0.05)$. The mean scores of participants can be seen in Table 9 (see Appendix C).

Table 9

Descriptive Statistics of Knowledge Across Age Groups (Knowledge)

\begin{tabular}{lllllllll}
\hline & \multirow{2}{*}{$\mathrm{N}$} & \multirow{2}{*}{ Mean } & \multirow{2}{*}{ Std. deviation } & \multirow{2}{*}{ Std. error } & \multicolumn{2}{c}{$95 \%$ confidence interval for mean } & \multirow{2}{*}{ Minimum } & \multirow{2}{*}{ Maximum } \\
\cline { 6 - 8 } & & & & & Lower bound & Upper bound & & \\
\hline $26-30$ & 16 & 12.0000 & 4.09878 & 1.02470 & 9.8159 & 14.1841 & 6.00 & 19.00 \\
$31-35$ & 11 & 13.4545 & 3.44568 & 1.03891 & 11.1397 & 15.7694 & 9.00 & 19.00 \\
$36-40$ & 3 & 9.3333 & 1.52753 & .88192 & 5.5388 & 13.1279 & 8.00 & 11.00 \\
Total & 30 & 12.2667 & 3.79594 & .69304 & 10.8492 & 13.6841 & 6.00 & 19.00 \\
\hline
\end{tabular}

$\mathrm{H}_{5}$ : Students' attitude is significantly predicted by their knowledge, gender and age.

This hypothesis assumes that variables as knowledge of English, respondents' age, and their sex can significantly predict attitude towards learning English. A multiple linear regression was used to test this hypothesis. It is used when we want to predict the value of a variable based on the value of two or more other variables; therefore, this test is used here to see whether any of the predictors shares significant variances with the variable to be predicted (attitude). The results suggested that the resulting model produced $\mathrm{R}^{2}=0.374$, Adj. $\mathrm{R}^{2}=0.302$, these outcomes explain that the regression model explains $37.4 \%$ of the variance in the dependent variable (attitude) when using the sample and $30 \%$ of the variances of the attitude when considering the whole population. Furthermore, the regression model was found to be significant in predicting the attitude, $\mathrm{F}(3,26)=$ $5.186, p<0.01$, however the only significant predictor was found to be knowledge of English $(\mathrm{B}=1.695, p<$ 0.01 ); this explains that for every unit increase in the knowledge variable, there is an increase of 1.695 in the attitude variable. Other predictors were not significant $(p>0.05$ ), as seen in Table 10 (see appendix C).

Table 10

Summary of the Model, Including Percentage of Variances Explained

\begin{tabular}{lllll}
\hline Model & $\mathrm{R}$ & $\mathrm{R}$ square & Adjusted R square & Std. error of the estimate \\
\hline 1 & $.612^{\mathrm{a}}$ & .374 & .302 & 8.55209 \\
\hline
\end{tabular}

\section{Discussion}

This study aims to measure the influence of English knowledge on the attitude to learn English. This study selected sample of Saudi students in Globe school. This sample was 30 students. The sample has students specialized in English, Physics, Social, and another. The main objective of this paper is to test Saudi students' attitude towards learning English and their knowledge of it. The five hypotheses were developed and a questionnaire was constructed that included demographic information (age, gender, and speciality); attitude and knowledge scales. Attitude and knowledge are two factors that are usually interrelated together. It was hypothesized that the attitude towards learning English is correlated with the knowledge of English. This hypothesis was developed based on studies that state the learners' attitude towards the language was found to be one of the vital factors influencing the language acquisition (Skehan, 1989; Dörnyei, 2005). This hypothesis was statistically assessed and it was concluded that it is true. A positive medium correlation was found between 
the two variables, which means that the positive attitude is related with the better the knowledge of English. It is understood that the positive students' mood about something the more likely they are to learn about it, this conclusion has supported by a number of findings in previous literature (Fakeye, 2010; Kara, 2009). In the Saudi context, this conclusion was supported by Scovel (1978, pp. 129-142) and Arnold (1999) who concluded that there is a positive relationship between both variables, however, it is often moderate. Such correlation is common sense and it is expected the passion to learn language leads to better knowledge. Even though this research's context is Saudi students, however, the environment is different (Globe school), this may have an impact on their attitude and knowledge compared to students who are actually in KSA (e.g., Fakeye, 2010). Being abroad may have improved the attitude and knowledge, as only a few number students; generally have high educational achievement; get the chance to study overseas, hence it is logical to think that they may have good knowledge of English as well as a more positive attitude. Skehan (1989) and Dörnyei (2005) reported that researchers argued that students' attitudes influence their ability of learning the language. The results of this study meet such argument. The sample of this research is practicing English in their academic lives; this may enhance their knowledge of English. Therefore, that may explain their attitude and knowledge and the relationship between them. Sex is often discussed in relation to many dependent variables, hence it was hypothesized that respondents' sex has a significant impact on their knowledge of English. Testing this hypothesis led to no significant difference between both sex (females and males), then this hypothesis was rejected. Moreover, as long as the sample is taken from one place, it is expected to not found many differences. There is evidence in the literature that some Saudi students experience a certain amount of anxiety when they are learning English, and this may affect female students more than males (Al-Saraj, 2014). It would have been more meaningful if participants had been recruited from different English schools too, which might have showed difference between both genders. However, such results may reveal that male and female in Saudi even though there are quite discrimination in the society in terms of jobs and education, they have the same attitude towards learning English both of them support learning English. It was hypothesized that respondents' attitude towards learning English is affected by their majors. This hypothesis was statistically approved; students with English major have better attitude towards learning and practicing English than others. This is expected because people with English major have good attitude to learning English; as long as they select this major, English might be their passion. These results contradict a conclusion made by Skehan (1989) and Dörnyei (2005), who found higher positive attitude amongst the more linguist-based specialities. Age is another factor tested in relation to knowledge; it was hypothesized that age has a significant impact on students' knowledge of English. This hypothesis was rejected. It could be argued that younger respondents may have more knowledge than the older groups due to the fact that younger people are more close to globalization and school's curriculum emphasized on English, not as old days. However, this was not proved with this study. Regression analysis was conducted in this study to test whether variables such as knowledge of English, gender, and age predict students' attitude towards learning English. Although a significant prediction was hypothesized, the results only showed that students' knowledge of science was the only significant predictor. This is a further confirmation for earlier conclusions in this study showing the association between knowledge and attitude. Gender was not found to significantly predict attitude and neither was students' age. The association between attitude and knowledge was discussed earlier in this section. Gender could not predict the attitude towards learning English, perhaps as a result of all respondents being (regardless of gender) in social courses (English, social) in the university. Their voluntary choice of their major could lead to positive attitudes towards English; but since all 
participants speak English, gender was not found to have an effect. As explained earlier, restricting the sample to students in Globe might have contributed to this similarity. Also, it should be highlighted that unlike many other tests, regression analysis is considered more powerful and more sensitive to the sample size; hence the use of a bigger sample could have led to more significant results.

\section{Conclusion}

The primary goal of this study was not to examine the reasons why the Saudi students were learning English but instead to examine whether different variables had an effect on students' knowledge of English and attitudes towards learning the language. There appears to be a positive correlation between attitudes and knowledge among the students surveyed and attitudes can be predicted by knowledge levels. This finding is of relevance to key policy-makers in developing nations such as Saudi Arabia as the encouragement of positive attitudes towards learning English will bring with it increased knowledge levels. Educational interventions that reflect this fact and treat English as a medium of science are required. The limitations of this study should be addressed and rectified in future studies. For example, the study sample could be expanded to include students who study in other English school besides the Globe institute, the sample size could be increased to achieve more generalizable findings and additional demographic data could be obtained. These measures would lead to a broader understanding of the relation between English language proficiency and attitudes towards learning.

\section{References}

Abidin, M. J. Z., Pour-Mohammadi, M., \& Alzwari, H. (2012). EFL students' attitudes towards learning English language: The case of Libyan secondary school students. Asian Social Science, 8(2), 119.

Al-Saraj, T. M. (2014). Foreign language anxiety in female Arabs learning English. Innovation in Language Learning and Teaching, 8(3), 257-278.

Arnold, J. (1999). Affect in language learning. Cambridge: Cambridge University Press.

Babbie, E. (2001). The practice of social research (9th ed.). Belmont, CA: Wadsworth Thomson.

Benson, P., \& Voller, P. (1997). Autonomy and independence in language learning. London: Longman.

Cherly Qing, L. (2010). A new Likert Scale based on Fuzzy Sets theory (Ph.D. dissertation, University of Connecticut, United States).

Davies, A. (2003). The native speaker: Myth and reality (2nd ed.). Clevedon: Multilingual Matters.

Dörnyei, Z. (1998). Motivation in second and foreign language learning. Cambridge: CILT/Cambridge University Press.

Dörnyei, Z. (2005). The psychology of the language learner: Individual differences in second language acquisition. Mahwah, NJ: Lawrence Erlbaum.

Dörnyei, Z. (2007). Research methods in applied linguistics: Quantitative, qualitative, and mixed methodologies. Oxford: Oxford University Press.

Fakeye, D. (2010). Students' personal variables as correlates of academic achievement in English as a second language in Nigeria. Journal of Social Sciences, 22(3), 205-211.

Field, A. (2009). Discovering statistics using SPSS (and sex and drugs and rock 'n' roll). Introducing statistical methods. London: Sage.

Findlow, S. (2006). Higher education and linguistic dualism in the Arab Gulf. British Journal of Sociology of Education, 27(1), 19-36.

Kara, A. (2009). The effect of a "Learning Theories" unit on students' attitudes towards learning. Australian Journal of Teacher Education, 34(3), 100-113. Retrieved August 10, 2011 from http://ro.ecu.edu.au/ajte/vol34/iss3/5

Karmani, S. (2005). Petro-linguistics: The emerging nexus between Oil, English and Islam. Journal of Language, Identity and Education, 4(2), 87-102.

Khan, I. A. (2011a). Learning difficulties in English: Diagnosis and pedagogy in Saudi Arabia. Educational Research, 2(7), $1248-1257$. 
Khan, I. A. (2011b). An analysis of learning barriers: The Saudi Arabian context. International Education Studies, 4 (1), $242-247$.

KSA Ministry of Education. (2006). Educational system in Saudi Arabia. Washington D.C.: Saudi Arabian Cultural Mission; Riyadh: MoE.

KSA Ministry of Education. (2010). The executive summary of the ministry of education ten year plan (2004-2014) (2nd ed.). Riyadh: MoE.

Murphy, C., \& Smith, G. (2012). The impact of a curriculum course on pre-service primary teachers' science content knowledge and attitudes towards teaching science. Irish Educational Studies, 31(1), 77-95. Retrieved February 28, 2014 from $\mathrm{http} / /$ web.b.ebscohost.com/ehost/detail?vid=5\&sid=3f4c615f-0ac0-4a67-9913-0006 cb907d45\%40sessionmgr114\&hid=108 \&bdata=JnNpdGU9ZWhvc3QtbG12ZQ\%3d\%3d\#db=ehh\&AN=73822188

Oppenheim, A. N. (1992). Questionnaire design, interviewing and attitude measurement (New ed.). London, Pinter.

Oppenheim, A. N. (2000). Questionnaire design, interviewing and attitude measurement. London: Continuum.

Pallant, J. (2013). SPSS survival manual. UK: McGraw-Hill Education.

Pennycook, A. D. (1994). The cultural politics of English as an international language. London: Longman.

Scovel, T. (1978). The effect of affect on foreign language learning: A review of the anxiety research. Language learning, 28(1), 129-142.

Seidman, I. (2013). Interviewing as qualitative research: A guide for researchers in education and the social sciences (3rd ed.). New York and London: Teachers College Press.

Skehan, P. (1989). Individual differences in second language learning. London: Edward Arnold.

Spiliotopoulou, G. (2009). Reliability reconsidered: Cronbach's alpha and paediatric assessment in occupational therapy. Australian Occupational Therapy Journal, 56, 150-155. Retrieved March 11, 2014 fromhttp://0-web.a.ebscohost.com.lib.exeter.ac.uk/ehost/resultsadvanced?sid=5ce4c8e4-2c77-41b5-bd9a-2345e1 f62453\%4se ssionmgr $4003 \& v i d=2 \&$ hid $=4206 \&$ bquery $=$ Reliability + reconsidered $\% 3 a+$ Cronbach's + alpha + AND + paediatric + assessment + \%22in\%22+occupational+therapy\&bdata=JmRiPWVvYWgmY2xpMD1GVCZjbHYwPVkmdHlwZT0xJnNpdGU9ZWhvc3 QtbG12ZQ\%3d\%3d

Syed, Z. (2005). TESOL in the Gulf: The sociocultural context of English language teaching in the Gulf. TESOL Quarterly, 37(2), 337-341.

Sywelem, M. M. G., \& Witte, J. E. (2013). Continuing professional development: Perceptions of elementary teachers in Saudi Arabia. Journal of Modern Education Review, 3(12), 881-898.

Troudi, S. (2007). The effects of English as a medium of instruction. In A. Jendli, S. Troudi, and C. Coombe (Eds.), The power of language: Perspectives from Arabia. Dubai: TESOL Arabia.

Young, D. J. (1991). Creating a low-anxiety classroom environment: What does the language anxiety research suggest? Modern Language Journal, 75(4), 426-437. 


\section{Appendix A}

Dear Participant,

I am an MSC student at the University of Exeter. The purpose of my study is to determine the degree of knowledge and attitudes of Saudi students towards opting and learning English language. All the responses of the respondents received through this research will be kept entirely confidential and will only be employed for data analysis of this study. I would be highly grateful if you would respond to each question in the questionnaire. Further, you would also have the choice to withdraw from participating in this research study. In case of any ambiguity or query; I will be available to discuss the questions related to the study; for this you can contact me via email, smaa204@exeter.ac.uk.

Thank you for your consideration, cooperation and valuable time.

Part 1: please choose the appropriate choice for you:

Name: (optional)

Gender: a) female b) male

Age: a) 20-25 b) 26-30 c) 31-35 d) 36-40

Your major is:

a) English b) physics c) social science d) other

Part 2: Please kindly put a tick $(\sqrt{ })$ in the box regarding your views towards English.

5) strongly agree 4) agree 3) neutral 2) disagree 1) strongly disagree.

\begin{tabular}{|c|c|c|c|c|c|c|}
\hline $\mathrm{N}$ & The items & $\begin{array}{l}1 \\
\mathrm{SD}\end{array}$ & $\begin{array}{l}2 \\
\mathrm{D} \\
\end{array}$ & $\begin{array}{l}3 \\
\mathrm{~N} \\
\end{array}$ & $\begin{array}{l}4 \\
\mathrm{~A} \\
\end{array}$ & $\begin{array}{l}5 \\
\text { SA } \\
\end{array}$ \\
\hline 1 & English classes are very important for me. & & & & & \\
\hline 2 & The English language is interesting subject. & & & & & \\
\hline 3 & I am eager to listen to BBC to improve my listening skill. & & & & & \\
\hline 4 & I find the English class difficult and boring. & & & & & \\
\hline 5 & Learning English is an important aim in my life. & & & & & \\
\hline 6 & The English concepts are complicated to understand. & & & & & \\
\hline 7 & English classes are not interesting. & & & & & \\
\hline 8 & I am not interested to attend English classes. & & & & & \\
\hline 9 & I like to speak English with my friends. & & & & & \\
\hline 10 & I am keen to read English newspaper. & & & & & \\
\hline 11 & I am not satisfied with my performance in the English subject. & & & & & \\
\hline 12 & I take part in English lessons to get a high mark. & & & & & \\
\hline 13 & I pay for additional classes to improve my English skills. & & & & & \\
\hline 14 & I don’t like English writing class. & & & & & \\
\hline 15 & English became important for everyone. & & & & & \\
\hline 16 & English help us to communicate with foreigners. & & & & & \\
\hline 17 & I cannot apply the knowledge from English subject in my real life. & & & & & \\
\hline 18 & Every person must learn English. & & & & & \\
\hline 19 & I like to imitate the British accent. & & & & & \\
\hline 20 & I don't pay any attention when my English teacher is explaining the lesson. & & & & & \\
\hline
\end{tabular}

\begin{tabular}{|l|l|}
\hline Vocabulary & (20) Items
\end{tabular}

\section{A: What do the underlined words mean?}

1. I like lazing on a beach with a pile of books.

a. standing $b$. doing nothing c. walking $d$. running 
2. My friend's a great artist. He drew my portrait and it looked just like me.

a. picture b. book c. face d. dress

3. You're a good cook. This casserole is absolutely delicious.

a. raw b. cooked c. salty d. taste good.

4. I had a hectic day at the office.

a. nice b. busy c. fast $d$. long

5. The number of people who are online increases by 100 million every year.

a. goes down b. changes c. goes up d. produced

\section{B: Choose the word that best completes the sentence:}

1. I like eating ............. food. I don't like herbs or spices at all.

a. ethnic b. sophisticated c. plain d. spicy.

2. Picasso was spoilt, but Hemingway's parents were

a. Lenient b. Strict_c. Good d. Understanding

3. Being a child has its own

a. Good and bad b. Rights and wrongs c. Pros and cons d. Better and worse

4. Romeo and Juliet is one of Shakespeare's

a. Master works b. Masterpieces b. Master plays d. Master poems

5.Dubai and Riyadh are cities.

a. Multinational b. Cosmopolitan_c. Cultural d. Historical

6. I am .............. a big decision. I am moving to London next month.

a. doing b. making $\mathrm{c}$.researching $\mathrm{d}$. doing for

7. The house we bought was left in a terrible mess. It was a start to life in our new home.

a. cheerful b. dangerous c. depressing c. fascinating

8. I complained to the manager because the secretary was.

a. helpful b. polite c. impolite d. kind

9. I could never .................. my iPhone. I reply to most of my e- mails while I am in the car.

a. do with b. do away with c. do without d. do up

10. Some explanations about Kennedy's death are Others are quite believable.

a. glued b. circulating $\mathrm{c}$. unanimously $\mathrm{d}$. potently ridiculous

11. I took back the broken TV and asked the shop to my money.

a. insult b. refund c. increase d. protest

12. I am very I want to be a well-known scientist.

a. ambition b. ambitious c. ambitiously d. ambitiousness

13. The documentary about water pollution has eating sea food.

a. put me on b. put me out c. put me away d. put me off

14. Emma Thompson, who Sense and sensibility for the screen, won the Oscar.

a. wrote b. captured c. adapted d. judged

15. When you go for a job interview, it's important to make a good

a. job b. impression c. suggestion d. difference. 


\title{
STUDENT RESEARCH MODULE/CASEWORK/ PLACEMENT \\ EXETER \\ Graduate School of Education \\ Certificate of ethical research approval
}

\section{MODULE/CASEWORK/PLACEMENT}

(there is a separate form for dissertations/theses).

To activate this certificate you need to first sign it yourself and then have it signed by your Tutor.

For further information on ethical educational research acess the guideling on the http://www.bera.ac.uk/publications/guidelines/

\section{READ THIS FORM CAREFULLY AND THEN COMPLETE IT ON YOUR COMPUTER (the form will expand to contain the text you enter). DO NOT COMPLETE BY HAND}

\author{
Your name: Sami Mohammed Almalki \\ Your student no: 630064023 \\ Return address for this certificate: Clydesdales Court, Flat 3, EX4 4QX \\ Degree/Programme of Study: 4 years doctoral of Education \\ Project Supervisor(s): Dr/Tom Ralph \\ Your email address: smaa204@exeter.ac.uk \\ Tel: 07413553888
}

I hereby certify that I will abide by the details given overleaf and that I undertake in my this research. I confirm that if my research should change radically, I will complete a further form. Signed:.....................date:...17/11/2014 NB For Masters dissertations, which are marked blind, this first page must not be included in your
work. It can be kept for your records. 


\section{Certificate of ethical research approval MODULE/CASEWORK/PLACEMENT}

Your student no: 630064023

Title of your research: Knowledge and attitudes towards learning English language in Exeter (UK), Saudi students.

Brief description of your research/casework :Give details of the methods to be used from data collection and analysis: In my research I will use a questionnaire which are divided into three parts in order to investigate the students' attitude and knowledge towards learning English. Part one : The questionnaire details the demographic information such as age, gender and the major. Part two : is About the attitudes towards learning English consisting of $20 \mathrm{ltems}$ measured by likert scales five point. Part there :Concerns knowledge of English vocabulary and consisting of 20 Items. The knowledge test includes multiples choices questions with four possible answers and there only one is true answer. The data will be coded using SPSS and analysed based on hypothesis.

Who are the participants in this research/casework? (giving ages of any children and/or young people involved): Saudi students in Exeter

Age : $20-40$ years old .

Gender : male and female

Grades : Bachelor, Master and doctoral students.

Give details of how you would address the following ethical issues: (with special reference to any children or those with special needs).

- informed consent. Where children in schools are involved this includes both headteachers and parents). An example of the consent form(s) must accompany this document. a blank consent form can be downloaded from the GSE student access on-line documents: All my participants are adults (20-40) years old.

- anonymity and confidentiality

All data collected will be stored in secure and safe place. For instant, all data and information will be stored on my personal computer which is secured by password .I will remain anonymous in the write up of my research so that I will use the letters $A, B$ etc referred to my participants.

- harm, detriment or unreasonable stress during data collection.

I will ask the participants if I see her/him is stressed or uncomfortable so that I will give her/him opportunity to withdraw if any participant asks me to chose time so that is convenience for her/him I will do. 
- storage of confidential material (videos/recorded interviews/photos/completed questionnaires).

All documents will be stored in secure and safe place which is in my personal computer with username and password.

This form should now be printed out, signed by you on the first page and sent to your supervisor to sign. This certificate will be returned to you to be included at the back of your assignment/dissertation/thesis.

Note: you should not commence your research/casework until you have the signature of your tutor

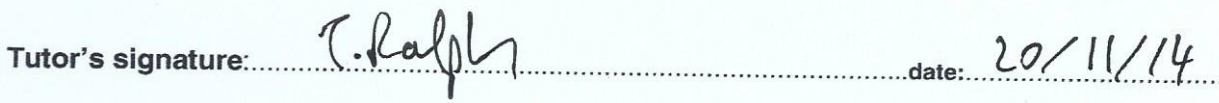

N.B. To Tutor:

The Chair of the GSE Ethics Committee Philip Durrant, is available to give advice or a ruling on all ethical issues in this study.

Please ensure that these ethical issues are addressed with your students before they complete this form. If returning the form by email, page 2 onwards should be converted into a pdf file and the first page then sent separately. 


\section{Appendix C}

\section{Reliability}

\section{Attitude}

Table C1

Reliability Statistics

\begin{tabular}{ll}
\hline Cronbach's alpha & N of items \\
.752 & 20 \\
\hline
\end{tabular}

Table C2

Item-Total Statistics

\begin{tabular}{lllll}
\hline & $\begin{array}{l}\text { Scale mean if item } \\
\text { deleted }\end{array}$ & $\begin{array}{l}\text { Scale variance if item } \\
\text { deleted }\end{array}$ & $\begin{array}{l}\text { Corrected item-total } \\
\text { correlation }\end{array}$ & $\begin{array}{l}\text { Cronbach's alpha if item } \\
\text { deleted }\end{array}$ \\
\hline E Important & 66.77 & 91.909 & .513 & .727 \\
E Interesting & 66.63 & 92.792 & .474 & .730 \\
BBC Listening & 67.63 & 85.964 & .675 & .710 \\
E difficult & 67.87 & 122.257 & -.678 & .811 \\
important Goal & 66.73 & 87.651 & .666 & .714 \\
E Complex & 67.10 & 97.197 & .320 & .742 \\
E boring & 66.67 & 91.540 & .582 & .724 \\
E_no_attend & 66.47 & 95.844 & .375 & .738 \\
E_Speak & 67.17 & 96.626 & .272 & .745 \\
E_read_news & 67.80 & 102.855 & -.004 & .770 \\
E_performance & 67.13 & 102.602 & .006 & .768 \\
E_getting_marks & 66.60 & 94.800 & .430 & .735 \\
E_pay_fees & 67.47 & 90.947 & .518 & .726 \\
E_hate_E & 67.00 & 90.000 & .503 & .726 \\
E_necessary & 66.60 & 91.697 & .487 & .729 \\
E_speak_foreign & 66.20 & 94.510 & .431 & .734 \\
E_life_practice & 67.40 & 95.352 & .307 & .743 \\
E_should_Learn & 66.90 & 92.990 & .414 & .734 \\
E_British_accent & 67.00 & 102.276 & .031 & .764 \\
E_no_interesting_class & 66.37 & 96.723 & .391 & .738 \\
\hline
\end{tabular}

\section{Knowledge}

Table C3

Reliability Statistics

\begin{tabular}{ll}
\hline Cronbach's alpha & N of items \\
.749 & 20 \\
\hline
\end{tabular}

Table C4

Item-Total Statistics

\begin{tabular}{lllll}
\hline & Scale mean if item deleted & $\begin{array}{l}\text { Scale variance if item } \\
\text { deleted }\end{array}$ & $\begin{array}{l}\text { Corrected item-total } \\
\text { correlation }\end{array}$ & $\begin{array}{l}\text { Cronbach's alpha if item } \\
\text { deleted }\end{array}$ \\
\hline Q1 & 11.43 & 14.185 & .028 & .757 \\
Q2 & 11.47 & 13.085 & .394 & .733 \\
Q3 & 11.47 & 13.637 & .202 & .746 \\
Q4 & 11.73 & 12.547 & .446 & .727 \\
Q5 & 11.57 & 14.254 & -.018 & .764 \\
Q6 & 11.73 & 13.237 & .248 & .744 \\
\hline
\end{tabular}


(Table C4 continued)

\begin{tabular}{lllll}
\hline & Scale mean if item deleted & $\begin{array}{l}\text { Scale variance if item } \\
\text { deleted }\end{array}$ & $\begin{array}{l}\text { Corrected item-total } \\
\text { correlation }\end{array}$ & $\begin{array}{l}\text { Cronbach's alpha if item } \\
\text { deleted }\end{array}$ \\
\hline Q7 & 11.53 & 13.568 & .193 & .748 \\
Q8 & 11.80 & 12.234 & .540 & .719 \\
Q9 & 11.87 & 12.257 & .546 & .719 \\
Q10 & 11.47 & 13.361 & .297 & .740 \\
Q11 & 11.60 & 13.903 & .077 & .757 \\
Q12 & 11.57 & 13.082 & .329 & .737 \\
Q13 & 11.63 & 12.723 & .414 & .730 \\
Q14 & 11.40 & 14.455 & -.063 & .760 \\
Q15 & 11.97 & 13.206 & .291 & .740 \\
Q16 & 11.70 & 12.010 & .614 & .712 \\
Q17 & 11.60 & 12.662 & .445 & .728 \\
Q18 & 12.03 & 13.275 & .303 & .739 \\
Q19 & 12.00 & 12.966 & .383 & .733 \\
Q20 & 11.50 & 12.879 & .436 & .730 \\
\hline
\end{tabular}
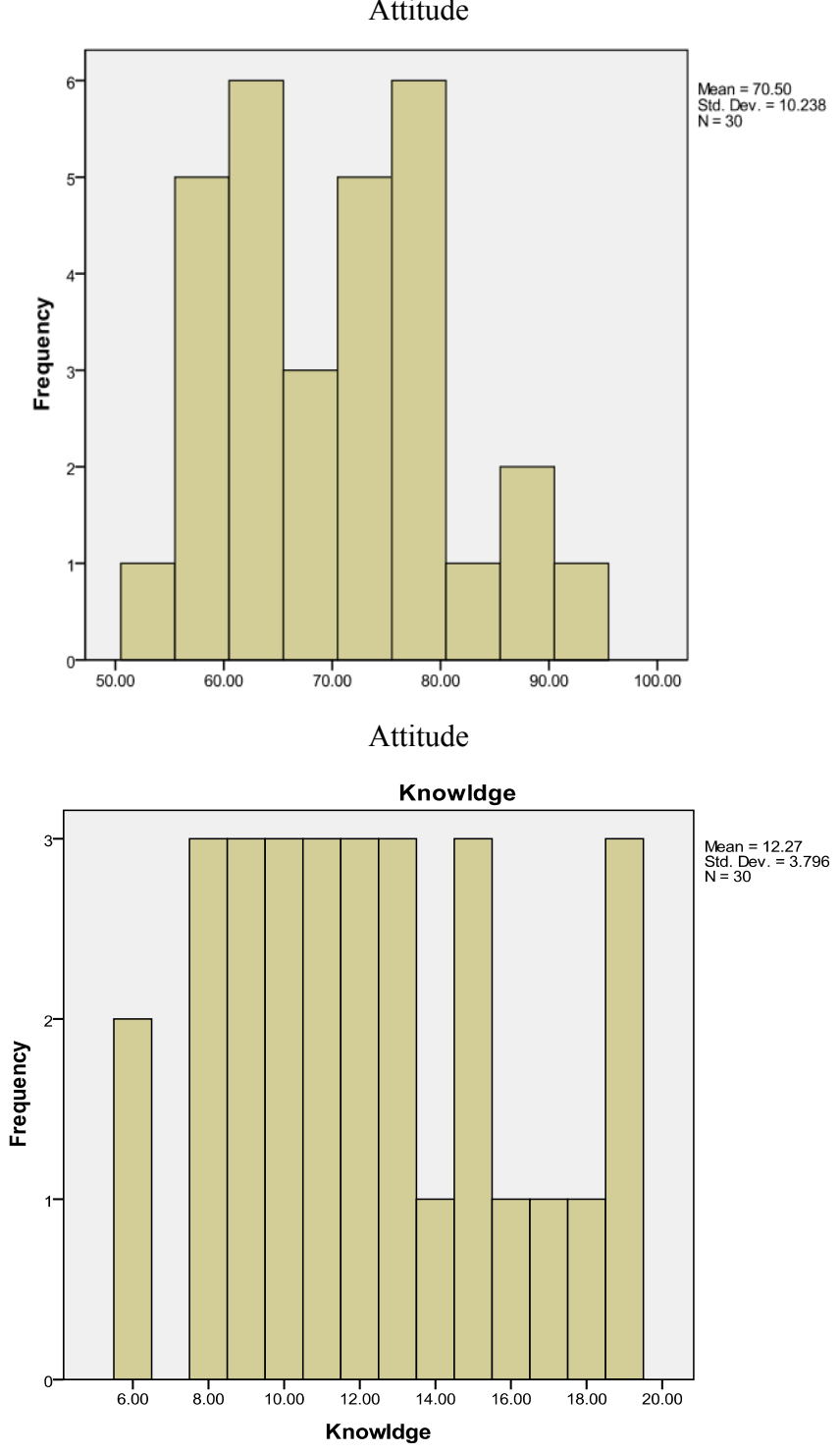
Table C5

General Descriptive Statistics of Attitude and Knowledge

\begin{tabular}{|c|c|c|c|c|}
\hline \multicolumn{5}{|l|}{ Descriptive } \\
\hline & & & Statistic & Std. Error \\
\hline \multirow{13}{*}{ Knowledge } & Mean & & 12.2667 & .69304 \\
\hline & \multirow{2}{*}{$95 \%$ confidence interval for mean } & Lower bound & 10.8492 & \\
\hline & & Upper bound & 13.6841 & \\
\hline & $5 \%$ trimmed mean & & 12.2407 & \\
\hline & Median & & 12.0000 & \\
\hline & Variance & & 14.409 & \\
\hline & Std. deviation & & 3.79594 & \\
\hline & Minimum & & 6.00 & \\
\hline & Maximum & & 19.00 & \\
\hline & Range & & 13.00 & \\
\hline & Interquartile range & & 6.00 & \\
\hline & Skewness & & .310 & .427 \\
\hline & Kurtosis & & -.757 & .833 \\
\hline \multirow{13}{*}{ Attitude } & Mean & & 70.5000 & 1.86914 \\
\hline & \multirow{2}{*}{$95 \%$ confidence interval for mean } & Lower bound & 66.6772 & \\
\hline & & Upper bound & 74.3228 & \\
\hline & $5 \%$ trimmed mean & & 70.2593 & \\
\hline & Median & & 70.0000 & \\
\hline & Variance & & 104.810 & \\
\hline & Std. deviation & & 10.23769 & \\
\hline & Minimum & & 53.00 & \\
\hline & Maximum & & 92.00 & \\
\hline & Range & & 39.00 & \\
\hline & Interquartile range & & 15.75 & \\
\hline & Skewness & & .331 & .427 \\
\hline & Kurtosis & & -.687 & .833 \\
\hline
\end{tabular}

Table C6

M-estimators

\begin{tabular}{lllll}
\hline & Huber's M-Estimator $^{\mathrm{a}}$ & Tukey's Biweight $^{\mathrm{b}}$ & Hampel's M-Estimator $^{\mathrm{c}}$ & Andrews' Wave $^{\mathrm{d}}$ \\
Knowledge & 12.0019 & 12.0414 & 12.1297 & 12.0423 \\
Attitude & 69.8670 & 69.9474 & 70.0069 & 69.9521 \\
\hline
\end{tabular}

Note. ${ }^{\text {a }}$. The weighting constant is $1.339 ;{ }^{b}$. The weighting constant is $4.685 ;{ }^{c}$. The weighting constants are $1.700,3.400$, and $8.500 ;{ }^{\text {d }}$. The weighting constant is $1.340 *$ pi.

Table C7

Percentiles

\begin{tabular}{|c|c|c|c|c|c|c|c|c|}
\hline & & \multicolumn{7}{|c|}{ Percentiles } \\
\hline & & 5 & 10 & 25 & 50 & 75 & 90 & 95 \\
\hline \multirow{2}{*}{$\begin{array}{l}\text { Weighted average } \\
\text { (Definition 1) }\end{array}$} & Knowledge & 6.0000 & 8.0000 & 9.0000 & 12.0000 & 15.0000 & 18.9000 & 19.0000 \\
\hline & Attitude & 55.2000 & 59.0000 & 61.7500 & 70.0000 & 77.5000 & 87.4000 & 90.3500 \\
\hline \multirow{2}{*}{ Tukey's Hinges } & Knowledge & & & 9.0000 & 12.0000 & 15.0000 & & \\
\hline & Attitude & & & 62.0000 & 70.0000 & 77.0000 & & \\
\hline
\end{tabular}


Table C8

Extreme Values in Attitude and Knowledge

\begin{tabular}{|c|c|c|c|c|}
\hline \multicolumn{5}{|c|}{ Extreme values } \\
\hline & & & Case number & Value \\
\hline \multirow{10}{*}{ Knowledge } & \multirow{5}{*}{ Highest } & 1 & 13 & 19.00 \\
\hline & & 2 & 21 & 19.00 \\
\hline & & 3 & 28 & 19.00 \\
\hline & & 4 & 27 & 18.00 \\
\hline & & 5 & 16 & 17.00 \\
\hline & \multirow{5}{*}{ Lowest } & 1 & 29 & 6.00 \\
\hline & & 2 & 24 & 6.00 \\
\hline & & 3 & 23 & 8.00 \\
\hline & & 4 & 15 & 8.00 \\
\hline & & 5 & 9 & 8.00 \\
\hline \multirow{10}{*}{ Attitude } & \multirow{5}{*}{ Highest } & 1 & 28 & 92.00 \\
\hline & & 2 & 16 & 89.00 \\
\hline & & 3 & 13 & 88.00 \\
\hline & & 4 & 2 & 82.00 \\
\hline & & 5 & 11 & $80.00^{\mathrm{a}}$ \\
\hline & \multirow{5}{*}{ Lowest } & 1 & 6 & 53.00 \\
\hline & & 2 & 24 & 57.00 \\
\hline & & 3 & 12 & 59.00 \\
\hline & & 4 & 7 & 59.00 \\
\hline & & 5 & 4 & 59.00 \\
\hline
\end{tabular}

Note ${ }^{\text {a }}$. Only a partial list of cases with the value 80.00 are shown in the table of upper extremes.

Table C9

Knowledge Stem-and-Leaf Plot

\begin{tabular}{ll}
\hline Frequency & Stem \& Leaf \\
\hline .00 & 0. \\
2.00 & 0.66 \\
6.00 & 0.888999 \\
6.00 & 1.000111 \\
6.00 & 1.222333 \\
4.00 & 1.4555 \\
2.00 & 1.67 \\
4.00 & 1.8999 \\
Stem width & 10.00 \\
Each leaf & 1 case(s) \\
\hline
\end{tabular}

Table C10

Attitude Stem-and-Leaf Plot

\begin{tabular}{|c|c|}
\hline Frequency & Stem \& Leaf \\
\hline 1.00 & 5.3 \\
\hline 4.00 & 5. 7999 \\
\hline 6.00 & 6. 012224 \\
\hline 4.00 & 6. 5899 \\
\hline 3.00 & 7. 124 \\
\hline
\end{tabular}


(Table $\mathrm{C} 10$ continued)

\begin{tabular}{ll}
\hline Frequency & Stem \& Leaf \\
\hline 6.00 & 7.556679 \\
3.00 & 8.002 \\
2.00 & 8.89 \\
1.00 & 9.2 \\
Stem width & 10.00 \\
Each leaf & 1 case(s) \\
\hline
\end{tabular}

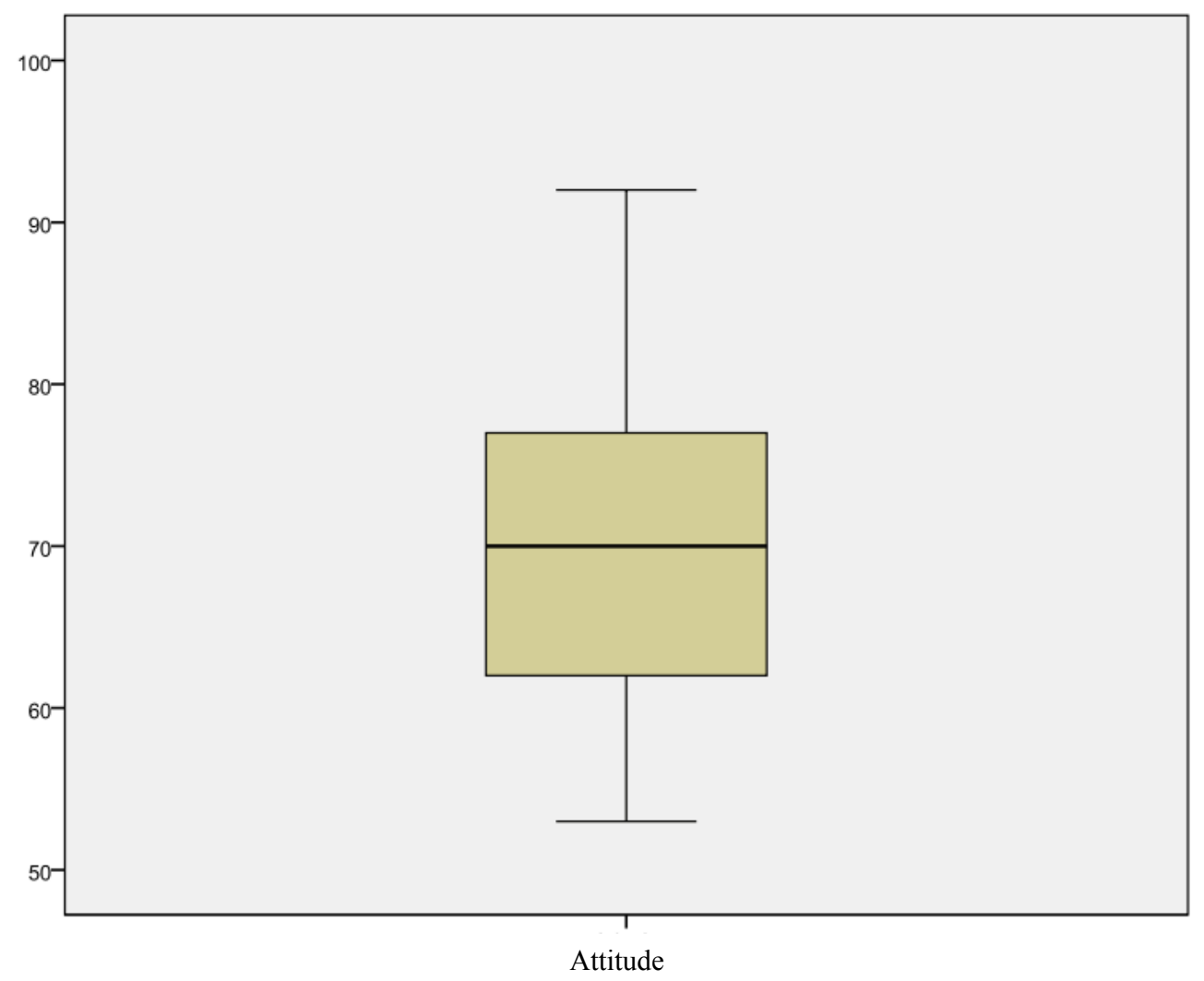

\section{Hypothesis Testing}

$\mathrm{H}_{1}$ : There is a significant correlation between students' knowledge of learning the English language and their attitude towards it.

\section{Table C11}

Correlation Coefficient and Its Significance Between Attitude and Knowledge

\begin{tabular}{llll}
\hline & & Knowledge & Attitude \\
\hline \multirow{3}{*}{ Knowledge } & Pearson correlation & 1 & $.594^{* *}$ \\
& Sig. (2-tailed) & & .001 \\
& $\mathrm{~N}$ & 30 & 30 \\
\hline \multirow{3}{*}{ Attitude } & Pearson correlation & $.594^{* *}$ & 1 \\
& Sig. (2-tailed) & .001 & \\
\hline
\end{tabular}

Note. ${ }^{* *}$. Correlation is significant at the 0.01 level (2-tailed). 
$\mathrm{H}_{2}$ : There is a significant influence of student's gender on their knowledge of learning the English language.

Table $\mathrm{C} 12$

Participants' Descriptive Statistics of Knowledge for Male and Female Students

\begin{tabular}{llllll}
\hline & Gender & $\mathrm{N}$ & Mean & Std. deviation & Std. error mean \\
\hline \multirow{2}{*}{ Knowledge } & Male & 17 & 11.5294 & 3.06426 & .74319 \\
& Female & 13 & 13.2308 & 4.53052 & 1.25654 \\
\hline
\end{tabular}

Table C13

Independent Samples T-Test Table Showing Homogeneity of Variances and Difference Between Groups

\begin{tabular}{|c|c|c|c|c|c|c|c|c|c|c|}
\hline & & \multicolumn{3}{|c|}{$\begin{array}{l}\text { Levene's test } \\
\text { for equality of } \\
\text { variances }\end{array}$} & \multicolumn{4}{|c|}{ T-test for equality of means } & & \\
\hline & & \multirow[t]{2}{*}{$\mathrm{F}$} & \multirow[t]{2}{*}{ Sig. } & \multirow[t]{2}{*}{$\mathrm{t}$} & \multirow[t]{2}{*}{ df } & \multirow[t]{2}{*}{$\begin{array}{l}\text { Sig. } \\
\text { (2-tailed) }\end{array}$} & \multirow[t]{2}{*}{$\begin{array}{l}\text { Mean } \\
\text { difference }\end{array}$} & \multirow[t]{2}{*}{$\begin{array}{l}\text { Std. error } \\
\text { difference }\end{array}$} & \multicolumn{2}{|c|}{$\begin{array}{l}95 \% \text { Confidence } \\
\text { interval of the } \\
\text { difference }\end{array}$} \\
\hline & & & & & & & & & Lower & Upper \\
\hline \multirow{2}{*}{ Knowledge } & $\begin{array}{l}\text { Equal variances } \\
\text { assumed }\end{array}$ & 3.289 & .080 & -1.227 & 28 & .230 & -1.70136 & 1.38653 & -4.54154 & 1.13883 \\
\hline & $\begin{array}{l}\text { Equal variances } \\
\text { not assumed }\end{array}$ & & & -1.165 & 20.026 & .258 & -1.70136 & 1.45987 & -4.74634 & 1.34363 \\
\hline
\end{tabular}

$\mathrm{H}_{3}$ : There is a significant influence of Students' speciality on their attitude towards learning English language.

Table $\mathrm{C} 14$

Descriptive Statistics of the Attitude Among Participants Based on Speciality

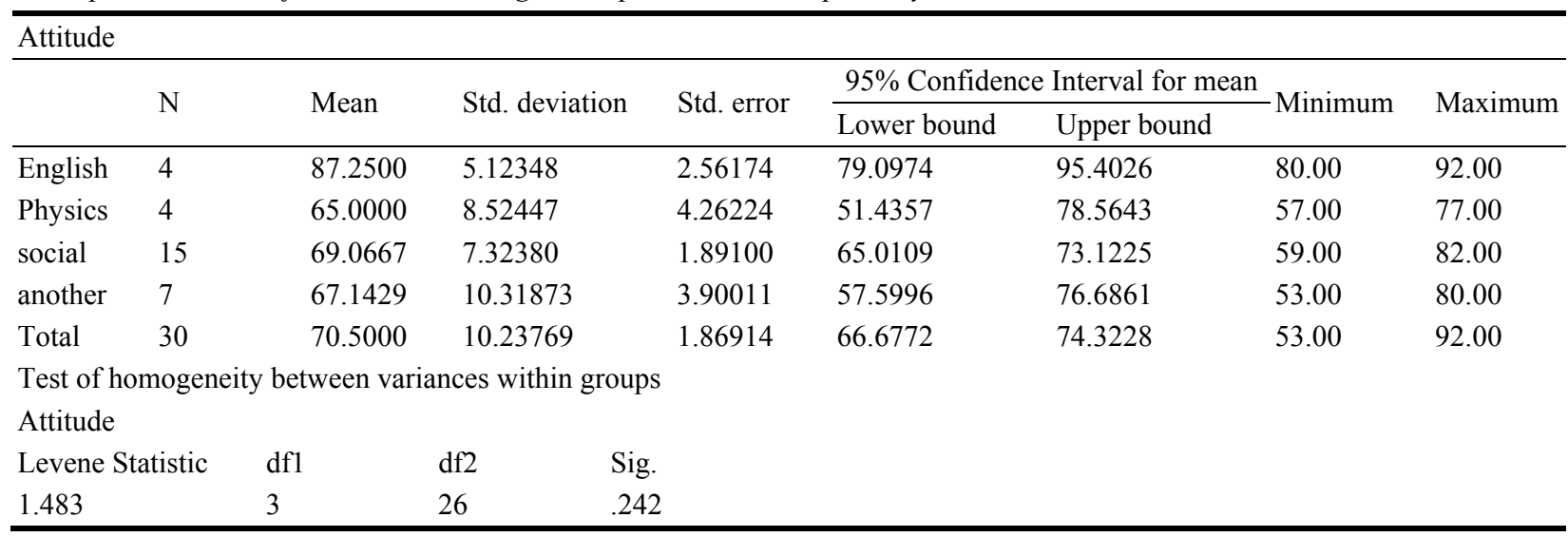

Note. *. The mean difference is significant at the 0.05 level.

Table C15

The Results of the ANOVA and Its Significance

\begin{tabular}{llllll}
\hline Attitude & \multicolumn{1}{l}{} & & \\
\hline & Sum of squares & Df & Mean square & F & Sig. \\
\hline Between groups & 1352.960 & 3 & 450.987 & 6.952 & .001 \\
Within groups & 1686.540 & 26 & 64.867 & & \\
Total & 3039.500 & 29 & & & \\
\hline
\end{tabular}


Table C16

Results of the Welch, Brown-Forsyth if No Homogeneity Existed

\begin{tabular}{lllll}
\hline Attitude & \multicolumn{3}{l}{} \\
\hline & Statistic & df1 & df2 & Sig. \\
\hline Welch & 11.786 & 3 & 8.446 & .002 \\
Brown-Forsythe & 6.968 & 3 & 14.193 & .004 \\
\hline
\end{tabular}

Note. a. Asymptotically F distributed.

Table $\mathrm{C} 17$

Dependent Variable: Attitude

Tukey HSD

\begin{tabular}{lllllll}
\hline \multirow{2}{*}{ (I) major } & \multirow{2}{*}{ (J) major } & Mean difference (I-J) & Std. error & \multirow{2}{*}{ Sig. } & \multicolumn{2}{c}{$95 \%$ confidence interval } \\
\cline { 6 - 7 } English & Physics & $22.25000^{*}$ & 5.69504 & .003 & 6.6267 & 37.8733 \\
& Social & $18.18333^{*}$ & 4.53224 & .002 & 5.7499 & 30.6167 \\
& Another & $20.10714^{*}$ & 5.04811 & .003 & 6.2586 & 33.9557 \\
\multirow{5}{*}{ Physics } & English & $-22.25000^{*}$ & 5.69504 & .003 & -37.8733 & -6.6267 \\
& Social & -4.06667 & 4.53224 & .806 & -16.5001 & 8.3667 \\
& Another & -2.14286 & 5.04811 & .974 & -15.9914 & 11.7057 \\
\multirow{3}{*}{ social } & English & $-18.18333^{*}$ & 4.53224 & .002 & -30.6167 & -5.7499 \\
& Physics & 4.06667 & 4.53224 & .806 & -8.3667 & 16.5001 \\
& Another & 1.92381 & 3.68662 & .953 & -8.1898 & 12.0374 \\
\multirow{3}{*}{ another } & English & $-20.10714^{*}$ & 5.04811 & .003 & -33.9557 & -6.2586 \\
& Physics & 2.14286 & 5.04811 & .974 & -11.7057 & 15.9914 \\
& social & -1.92381 & 3.68662 & .953 & -12.0374 & 8.1898 \\
\hline
\end{tabular}

$\mathrm{H}_{4}$ : Age has a significant influence on students' knowledge and learning of the English language.

Table C18

Descriptive Statistics of Knowledge Across Age Groups

\begin{tabular}{|c|c|c|c|c|c|c|c|c|}
\hline \multicolumn{9}{|c|}{ Knowledge } \\
\hline & \multirow{2}{*}{$\mathrm{N}$} & \multirow{2}{*}{ Mean } & \multirow{2}{*}{ Std. deviation } & \multirow{2}{*}{ Std. error } & \multicolumn{2}{|c|}{$95 \%$ confidence interval for mean } & \multirow{2}{*}{-Minimum } & \multirow{2}{*}{ Maximum } \\
\hline & & & & & Lower Bound & Upper Bound & & \\
\hline $26-30$ & 16 & 12.0000 & 4.09878 & 1.02470 & 9.8159 & 14.1841 & 6.00 & 19.00 \\
\hline $31-35$ & 11 & 13.4545 & 3.44568 & 1.03891 & 11.1397 & 15.7694 & 9.00 & 19.00 \\
\hline $36-40$ & 3 & 9.3333 & 1.52753 & .88192 & 5.5388 & 13.1279 & 8.00 & 11.00 \\
\hline Total & 30 & 12.2667 & 3.79594 & .69304 & 10.8492 & 13.6841 & 6.00 & 19.00 \\
\hline
\end{tabular}

Table C19

Tests of Homogeneity of Variances

\begin{tabular}{llll}
\hline Knowledge & & & \\
\hline Levene Statistic & df1 & df2 \\
1.714 & 2 & 27 & .199 \\
\hline
\end{tabular}


Table C20

ANOVA Results Between Groups

\begin{tabular}{llllll}
\hline Knowledge & \multicolumn{1}{l}{} & & \\
\hline & Sum of squares & df & Mean square & F & Sig. \\
\hline Between groups & 42.473 & 2 & 21.236 & 1.527 & .235 \\
Within groups & 375.394 & 27 & 13.903 & & \\
Total & 417.867 & 29 & & & \\
\hline
\end{tabular}

Table C21

Tukey HSD Post-Hoc Test for Multiple Comparisons

\begin{tabular}{lllllll}
\hline \multicolumn{2}{l}{$\begin{array}{l}\text { Knowledge } \\
\text { Tukey HSD }\end{array}$} \\
\cline { 5 - 7 }$(\mathrm{I})$ age & (J) age & Mean difference (I-J) & Std. error & Sig. & \multicolumn{2}{c}{ 95\% confidence interval } \\
\cline { 5 - 7 } $26-30$ & $31-35$ & -1.45455 & 1.46045 & .586 & -5.0756 & 2.1665 \\
& $36-40$ & 2.66667 & 2.34595 & .500 & -3.1499 & 8.4832 \\
\hline \multirow{2}{*}{$31-35$} & $26-30$ & 1.45455 & 1.46045 & .586 & -2.1665 & 5.0756 \\
& $36-40$ & 4.12121 & 2.42867 & .225 & -1.9005 & 10.1429 \\
\hline \multirow{2}{*}{$36-40$} & $26-30$ & -2.66667 & 2.34595 & .500 & -8.4832 & 3.1499 \\
& $31-35$ & -4.12121 & 2.42867 & .225 & -10.1429 & 1.9005 \\
\hline
\end{tabular}

$\mathrm{H}_{5}$ : Students' attitude is significantly predicted by their knowledge, gender and age.

Table C22

Summary of the Model, Including Percentage of Variances Explained

\begin{tabular}{lllll}
\hline Model & $\mathrm{R}$ & R square & Adjusted R square & Std. error of the estimate \\
\hline 1 & $.612^{\mathrm{a}}$ & .374 & .302 & 8.55209
\end{tabular}

Note. ${ }^{\text {a }}$. Predictors: (Constant), age, gender, knowledge

Table C23

ANOVA Outcome Displaying the Significance of the Regression Model

\begin{tabular}{lllllll}
\hline ANOVAb & \multicolumn{1}{l}{} \\
\hline Model & & Sum of Squares & df & Mean Square & F & Sig. \\
\hline \multirow{3}{*}{1} & Regression & 1137.904 & 3 & 379.301 & 5.186 & $.006^{\text {a }}$ \\
& Residual & 1901.596 & 26 & 73.138 & & \\
& Total & 3039.500 & 29 & & & \\
\hline
\end{tabular}

Note. ${ }^{a}$. Predictors: (Constant), age, gender, knowledge; ${ }^{b}$. Dependent variable: attitude.

Table C24

Coefficients of Each Predictor and Their Significance

\begin{tabular}{|c|c|c|c|c|c|c|}
\hline \multirow{2}{*}{ Model } & & \multicolumn{2}{|c|}{ Unstandardized coefficients } & Standardized Coefficients & & \multirow{2}{*}{ Sig. } \\
\hline & & $\mathrm{B}$ & Std. Error & Beta & & \\
\hline \multirow{4}{*}{1} & (Constant) & 53.727 & 9.042 & & 5.942 & .000 \\
\hline & Knowledge & 1.695 & .430 & .628 & 3.941 & .001 \\
\hline & gender & -3.080 & 3.235 & -.152 & -.952 & .350 \\
\hline & age & .154 & 2.344 & .010 & .066 & .948 \\
\hline
\end{tabular}

Note. a. Dependent variable: attitude. 